${ }^{1}$ КЗ «Криворізьке училище підвищення кваліфікації та перепідготовки молодших медичних і фармацевтичних спеціалістів» ДОР

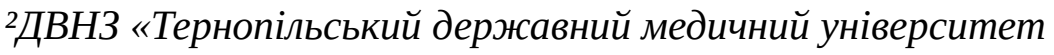
імені І. Я. Горбачевського МОЗ України»

\title{
ФОРМУВАННЯ ПРАВОВОЇ КОМПЕТЕНТНОСТІ КЕРІВНИКІВ МЕДСЕСТРИНСТВА НА ЕТАПІ ПІСЛЯДИПЛОМНОЇ ОСВІТИ
}

\author{
N. I. Savytska', O. M. Mochulska² \\ ${ }^{1}$ Kryvyi Rih Advanced Training and Retraining School of \\ Junior Medical and Pharmaceutical Specialists \\ ${ }^{2}$ I. Horbachevsky Ternopil State Medical University

\section{FORMATION OF LEGAL COMPETENCE OF NURSERY LEADERS AT THE STAGE OF POSTGRADUATE EDUCATION}

\begin{abstract}
Анотація. У статті розглянуто і досліджено сучасні тенденції розвитку правової освіти громадян, становлення правових інституцій, утвердження верховенства права в усіх сферах буття і функціонування суспільства. Виокремлено актуальні питання юридичного забезпечення прав громадян у галузі охорони здоров’я і питання якості юридичної бази організації та здійснення медичної діяльності в Україні. Проаналізовано особистий досвід та представлено результати впровадження у навчальному комунальному закладі «Криворізьке училище підвищення кваліфікації та перепідготовки молодших медичних і фармацевтичних спеціалістів» ДОР у 2016-2017 та 2017-2018 навчальних роках короткотермінового циклу тематичного удосконалення (ТУ) «Медичне право» для керівників медсестринських служб закладів охорони здоров’я Дніпропетровської області. Проведено оцінку рівня правових знань керівників медсестринства. Наведено результати комп’ютерного вхідного (базового) тестового контролю та підсумкового тестування, які свідчать, що рівень отриманих слухачами знань під час навчання значно перевищує рівень їх базових знань.

Представлені нами матеріали показали, що проведення циклу тематичного удосконалення з медичного права, як сучасної навчальної дисципліни, є особливо актуальним та необхідним, сприяє розвитку професійних компетенцій слухачів на етапі післядипломного навчання керівників медсестринства. Навчання на циклі тематичного удосконалення (ТУ) «Медичне право» дозволяє слухачам набути необхідного обсягу правових знань та сформувати навички і вміння вирішення складних управлінських задач щодо правовідносин між медичними працівниками і пацієнтами.
\end{abstract}

Ключові слова: медичне право; права людини; керівники медсестринства; компетенції.

Abstract. The modern tendencies in development of legal education of citizens, formation of legal institutions, establishment of the rule of law in all spheres of life and functioning of society were considered and researched in the article. The actual issues of legal protection of citizens' rights in the field of health care and quality of legal base of the organization and implementation of medical activity in Ukraine were highlighted. The personal experience was analyzed and the results of implementation in the educational institution at "Kryvyi Rih Advanced Training and Retraining School of Junior Medical and Pharmaceutical Specialists" in 2016 -2017 and 2017-2018 academic years of the short-term cycle of thematic improvement (TI) "Medical Law" for heads of nursing services of health facilities in Dnipropetrovsk region were presented. Assessment of the level of legal knowledge of nursing heads was conducted. The results of computer input (basic) test control and final test control presented that the level of knowledge obtained by students during the training significantly exceeds the level of their basic knowledge.

The presented material have shown that the cycle of thematic improvement in medical law, as a modern educational discipline, is especially important and necessary, promotes professional competencies of specialists at the stage of postgraduate training heads of nursing. Teaching on the thematic improvement course "Medical Law" allows students to acquire the required amount of legal knowledge and to develop skills and ability to solve complex management tasks regarding the legal relationship between healthcare workers and patients.

Key words: medical law; human rights; heads of nursing; competencies. 
Вступ. Ефективність діяльності медичних закладів і якість надання медичної допомоги населенню залежать не тільки від професійного рівня медичних і фармацевтичних спеціалістів, а й від свідомого формування у них правового мислення, що дозволить попередити можливі правопорушення, дасть можливість відстоювати та захищати права пацієнтів і власні права [2, 4].

Останнє десятиліття позначилося інтенсивним розвитком в Україні медичного права як утворення в системі права, науки, навчальної дисципліни і сфери юридичної практики. Напрями розвитку медичного права України, окреслені на етапі його становлення, залишаються визначальними і досі. Проблеми медичного права досліджено в роботах багатьох вітчизняних і зарубіжних науковців, таких, як Р. Гревцова, А. Степаненко, С. Істомін, Н. Кризина, Я. Радиш, 3. Гладун, А. Кемпбелл, К. Бузаджі, Я. Кеннеді [1-3, 5]. Останнім часом, з розвитком міжнародно-правових і національних механізмів захисту прав людини у сфері охорони здоров’я, тісний зв'язок між медичним правом (правом охорони здоров’я) і правами людини стає все більш очевидним. Відомі британські вчені Я. Кеннеді та Е. Граб навіть висловили переконання в тому, що медичне право є підгалуззю «права прав людини» (Human Rights Law) [5]. Вітчизняні дослідники C. Стеценко, В. Стеценко та I. Сенюта вважають, що «права населення в галузі охорони здоров’я» $€$ підгалуззю медичного права як окремої галузі права, а права людини в галузі охорони здоров’ я є важливим елементом загальної частини системи медичного права як навчальної дисципліни [2-4].

За даними аналізу останніх досліджень та публікацій, в Україні правові аспекти здійснення медичної діяльності сьогодні перебувають на стадії становлення та формування [1-3], тому в даній статті ми розглянули шляхи вдосконалення навчального процесу у формуванні правової компетентності медичних спеціалістів. Сучасна медична практика вимагає від спеціалістів не лише правової поінформованості, а й достатнього рівня правових знань, які доводиться застосовувати у щоденній професійній діяльності. Таким чином, формування правового мислення не можна відокремлювати від практичної підготовки медичних спеціалістів. Отримання знань з медичного права є необхідною складовою додипломної та післядипломної професійної підготовки молодших медичних спеціалістів.

Мета статті - проаналізувати результати та визначити основні завдання подальшого вдоскона- лення навчального процесу у формуванні правової компетентності керівників медсестринства на етапі післядипломної освіти.

Теоретична частина. Вважається, що одним із важливих елементів захисту прав людини є розширення її обізнаності стосовно своїх прав і способів їх захисту. Оволодіння правовою культурою дає орієнтир кожному громадянину в оцінці складних суспільних процесів та можливість відстоювати свої права від будь-яких їх обмежень.

Розбудова правової демократичної держави передбачає розвиток правової освіти її громадян, становлення правових інституцій, утвердження верховенства права в усіх сферах буття та функціонування суспільства. Питання юридичного забезпечення медичної діяльності в Україні останнім часом набувають особливої актуальності. Це передусім пов'язане з активним розвитком приватної медичної практики, використанням новітніх досягнень медичної науки (трансплантологія, репродуктивні технології, клонування), удосконаленням управлінської діяльності в галузі охорони здоров’я тощо. Головним питанням медичного права є законодавче забезпечення прав громадян у галузі охорони здоров'я. Правова база охорони здоров'я $є$ дуже нечіткою, нерідко зустрічаються законодавчі колізії та ситуації, коли норми різних актів, що регламентують відносини у сфері охорони здоров’я, суперечать один одному.

Особливістю медичного права $є$ його універсальний характер, тому що воно одночасно логічно вбудовується в структуру як юридичних, так і медичних дисциплін. Предмет медичного права це суспільні відносини, що виникають у процесі здійснення медичної діяльності. Вони складаються об’ єктивно, поза волею і свідомістю окремо взятої людини або групи людей. Професор Я. Ф. Радиш, посилаючись на думку молдавського дослідника В. Флорі, стверджує [2, 3]: медичне право - це сукупність юридичних норм, що регулюють правовідносини між медичним працівником і медичним закладом, з одного боку, та пацієнтом і його родичами - 3 другого, що виникають з приводу надання медичної допомоги та мають за мету попередження лікарських помилок і правопорушень, захист медичного персоналу від відповідальності при обгрунтованому ризику та за умови невинного спричинення шкоди [2, 3]. Професор С. Г. Стеценко медичне право визначив так: це комплексна галузь права, що включає сукупність правових норм, які регулюють суспільні відносини у сфері медичної 
діяльності і можуть претендувати на правову, етичну та професійну значущість [1, 2].

Медичне право дає можливість на більш високому рівні впроваджувати принципи державної політики у сфері охорони здоров'я, якісніше опрацьовувати питання захисту прав громадян під час надання медичної допомоги, детально визначати правовий статус суб’ єктів правовідносин, що виникають у галузі медичної діяльності.

Відомо, що система охорони здоров’я і процеси надання медичної допомоги потребують регулювання. Завдяки праву ці процеси набувають впорядкованості і таким чином стають правовими відносинами. Специфічними рисами суспільних відносин, що регулюються за допомогою медичного права, є ті, що виникають, існують і розвиваються відповідно до особистісних немайнових благ людини - життя та здоров'я.

Зацікавленість питаннями правового регулювання медичної діяльності в Україні пояснюється низкою ключових факторів, що й зумовлюють потребу українського суспільства в знаннях у сфері нормативно-правового забезпечення медичної діяльності, серед яких найважливішими є такі:

- зростання кількості нормативно-правових актів системи охорони здоров’я України;

- потреби практичної діяльності медичних закладів, де найчастіше й виникають проблеми медикоправового характеру;

- запити юридичної практики, що свідчать про зростання ролі спеціальних знань, пов'язаних 3 особливостями правового регулювання медичної діяльності;

- підвищення правової грамотності населення у сфері отримання медичних послуг, що виявляється у збільшенні кількості скарг та позовних вимог у разі надання медичної допомоги незадовільної якості.

Першочерговими завданнями державної політики України у галузі охорони здоров’я на стадії розбудови та утвердження їі як демократично незалежної держави має стати: 1) удосконалення системи законодавчого забезпечення діяльності сфери охорони громадського здоров’я за рахунок підготовки, затвердження та впровадження у життя відповідних законодавчих актів; 2) удосконалення післядипломної підготовки, перепідготовки і підвищення кваліфікації керівників та відповідних фахівців і професіоналів у цій важливій сфері суспільного життя.

Так, на сторінках журналу «Український медичний часопис» [1] викладено теоретичне обгрун- тування місії та стратегії правової складової післядипломної підготовки керівників для системи охорони здоров'я України й кадрового резерву у контексті сучасних імперативів верховенства права. На цій основі здійснено постановку проблеми щодо нагальної необхідності введення комплексної навчальної дисципліни «Медичне право» до програми післядипломної підготовки сучасних керівників галузі охорони здоров’я України та розроблено структуру і визначено основні цілі дисципліни. Доцільно окремо зупинитися на обгрунтуванні ролі та місця права охорони здоров’я у навчальному процесі на рівні післядипломної освіти керівників системи охорони здоров'я, до яких належать і керівники медсестринських служб, а це головні медичні сестри, акушерки, фельдшери та старші медичні сестри закладів охорони здоров’я.

Впродовж останніх років традиційне сприйняття медичних професій як мистецтва, а не як ремесла, стало змінюватися. Розвиток законодавства, контроль якості медичної допомоги, несприятливі наслідки медичного втручання - ось далеко не повний перелік причин, що сприяють підвищенню «юридизації» цих професій [4]. Реальні умови медичної практики зі всією очевидністю демонструють, що медичний спеціаліст, який не знає своїх прав та обов'язків і тієї межі, за якою настає відповідальність, не може бути допущеним до професійної практики. Ще більшою мірою це стосується професійної компетентності (чи некомпетентності) керівників різних рівнів системи охорони здоров'я. На необхідність належної правової компетентності медичних працівників вказують різні фактори, ключовими $з$ яких є такі:

- часті та суттєві зміни нормативно-правової бази з надання медичної допомоги;

- активний розвиток приватної медицини;

- надання платних медичних послуг у державних та комунальних медичних закладах;

- розвиток добровільного медичного страхування;

- можливість для пацієнта усіма доступними засобами, у тому числі й шляхом звернення до суду, захищати свої права під час отримання медичної допомоги тощо.

Окрім того, особливої актуальності правова складова післядипломної підготовки набуває з огляду на проведення в державі правової реформи, у процесі якої планується прийняття багатьох нових законів, створення ефективної національної правової системи, що дасть змогу Україні інтегруватися в Європейський правовий простір, сформувати 
ефективні інститути громадянського суспільства та побудувати дійсно демократичну, соціальну, правову державу. Підвищення рівня правових знань у керівників різних рівнів системи охорони здоров’я України, їх правової свідомості та правової культури можливі лише за умови системного, професійно організованого правового виховання, що здійснюється з використанням усіх його форм, у тому числі й післядипломної підготовки.

3 метою підвищення рівня професійної компетентності фахівців у галузі права та управління системою охорони здоров'я у навчальному комунальному закладі «Криворізьке училище підвищення кваліфікації та перепідготовки молодших медичних і фармацевтичних спеціалістів» ДОР розроблено та у 2016-2017 та 2017-2018 навчальних роках започатковано проведення короткотермінового циклу тематичного удосконалення (ТУ) «Медичне право» для керівників медсестринських служб закладів охорони здоров'я Дніпропетровської області. Тривалість циклу - 0,25 місяця або один тиждень. Навчання здійснюється за 36-годинною навчальною програмою. На наше переконання, правова складова програми післядипломної освіти має базуватися на між- та багатодисциплінарній моделі підготовки фахівців і повинна передбачати навчальні курси, що виступають системоутворювальним чинником у процесі розкриття сутності права в охороні здоров'я. Опанування навчального матеріалу циклу передбачає набуття слухачами визначених знань та формування навичок і вмінь.

Перелік професійних знань молодших медичних спеціалістів з медичного права

1. Поняття, предмет конституційного права.

2. Структура Конституції України.

3. Конституційно-правовий статус людини і громадянина в Україні.

4. Закон України «Основи законодавства України про охорону здоров'я».

5. Міжнародно-правові стандарти у сфері охорони здоров'я.

6. Права та обов'язки медичних працівників.

7. Правовий статус медичної сестри, акушерки, фельдшера.

8. Визначення поняття «пацієнт», права та обов’язки пацієнтів.

9. Характеристика загальних і спеціальних прав пацієнтів.

10. Європейська хартія прав пацієнтів.

11. Поняття «інформованої згоди» на медичне втручання у національному законодавстві.
12. Юридичний конфлікт у медицині.

13. Дефекти надання медичної допомоги: «лікарська» та «медична» помилка; нещасний випадок, проступок, злочин.

14. Юридична відповідальність медичних працівників, види юридичної відповідальності.

15. Адміністративна та дисциплінарна відповідальність медичних працівників.

16. Форми захисту прав пацієнтів.

Перелік професійних навичок та вмінь молодших медичних спеціалістів з медичного права

1. Своєчасно та компетентно виявляти, перевіряти й оцінювати докази і фактичні обставини порушення прав пацієнтів та медичних працівників, що виникають у процесі надання медичної допомоги.

2. Вміти обирати та аналізувати правові норми медичного права в процесі їх фактичного застосування.

3. Приймати рішення, у межах повноважень, 3 правових питань, що виникають у процесі надання медичної допомоги населенню.

4. Впроваджувати правове виховання медичних працівників.

5. Вміти оформлювати інформовану добровільну згоду на медичне втручання в межах посадових обов'язків та повноважень.

6. Попереджувати виникнення юридичних конфліктів між медичним персоналом і пацієнтами, пов'язаних із дефектами надання медичної допомоги.

7. Застосовувати примирювальні заходи з метою захисту прав пацієнтів у закладах охорони здоров'я.

Сучасна медична практика вимагає від спеціалістів не лише правової поінформованості, а й достатнього рівня правових знань, що доводиться застосовувати у щоденній професійній діяльності. Отже, формування правового мислення не можна відокремлювати від практичної підготовки медичних спеціалістів. Отримання ними знань 3 медичного права $€$ необхідною складовою професійної підготовки на етапі післядипломної освіти.

Метою викладання медичного права $€$ комплексна підготовка медичних працівників, які, отримуючи необхідний обсяг правових знань, знатимуть механізми правореалізації, володітимуть достатнім рівнем правової культури і правосвідомості для здійснення взаємин між суб'єктами медичних правовідносин і дотримання прав людини у сфері охорони здоров'я. За два навчальних роки було організовано та проведено 7 циклів ТУ, на яких пройшли навчан- 
ня 99 керівників медсестринських служб закладів охорони здоров’ я (рис. 1).

Розпочинається цикл тематичного удосконалення 3 комп’ютерного тестування, що дає можливість встановити рівень базових правових знань молодших медичних спеціалістів. Обсяг і складність тестових завдань мінімальні. Оцінювання знань здійснюється за п’ятибальною шкалою.
3 метою виявлення рівня правових знань керівників медсестринських служб різного рангу 3 контингенту слухачів було виділено дві групи: головні медичні сестри та старші медичні сестри. Проведено аналіз відповідей слухачів з кожного тестового питання. Для детального аналізу усі питання було згруповано за напрямками правових знань (табл. 1).

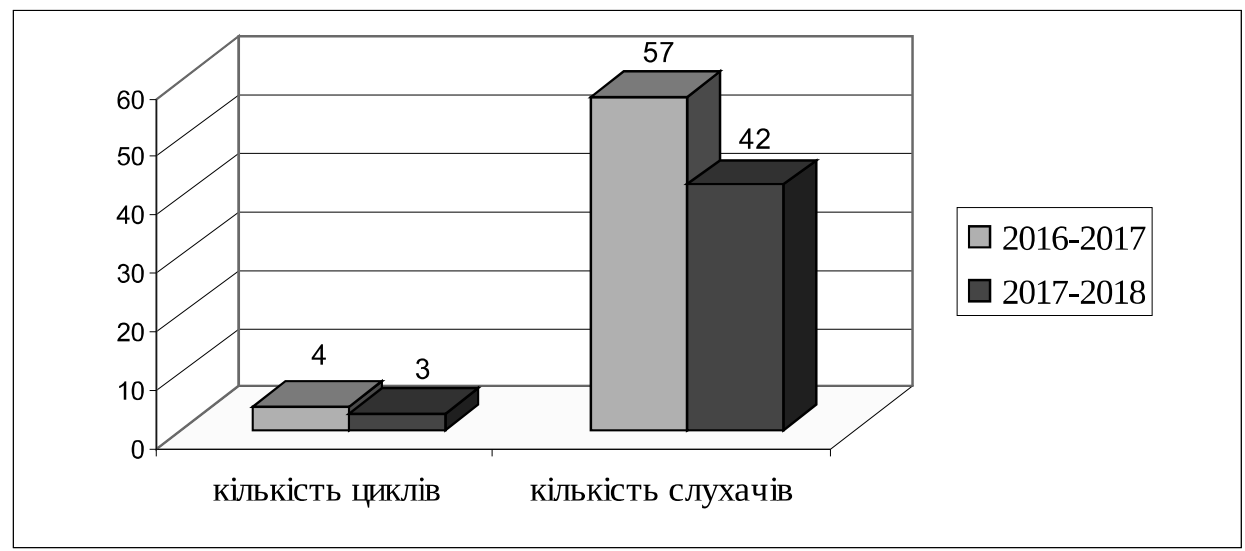

Рис. 1. Проведення циклів ТУ «Медичне право».

Таблиця 1. Групи тестових завдань вхідного та вихідного контролю за напрямками правових знань

\begin{tabular}{|l|c|c|}
\hline \multicolumn{1}{|c|}{ Напрямки правових знань } & $\begin{array}{c}\text { Кількість запитань вхідного } \\
\text { контролю }\end{array}$ & $\begin{array}{c}\text { Кількість запитань вихідного } \\
\text { контролю }\end{array}$ \\
\hline Поняття & 5 & 6 \\
\hline Нормативно-правові акти & 1 & 5 \\
\hline Права та обов'язки суб’єктів правовідносин & 5 & 9 \\
\hline Правова відповідальність & 4 & 25 \\
\hline Всього & 15 & 5 \\
\hline
\end{tabular}

Це дозволило визначити групи запитань, на які не змогли відповісти головні та старші медичні сестри (рис. 2).

Тобто серед головних медичних сестер, як показує аналіз, рівень базових правових знань вищий, ніж серед старших медичних сестер. Так, наприклад, знання нормативно-правових актів головними медичними сестрами взагалі не викликають сумніву - жодної неправильної відповіді не надано. Стосовно інших груп тестових питань теж маємо значну перевагу рівнів знань головних медичних сестер закладів охорони здоров’я. Варто відмітити, що рівень знань із медичного права не задовольняє і самих медичних спеціалістів та викликає у них занепокоєння.

Відпрацюванню практичних навичок та вмінь сприяє розбір конкретних ситуацій та розв’язання ситуаційних задач, до яких слухачі виявляють неабиякий інтерес. Важливо зауважити, що всі задачі мають реалістичну основу, оскільки сюжети запози- чені з повсякденних взаємин між суб’єктами медичних правовідносин. Для пошуку розв’ язання ситуацій слухачам пропонується користуватися нормативно-правовою базою і літературними джерелами.

По завершенні навчання медичні спеціалісти повинні набути навичок правового аналізу та правового мислення, отримати знання про закони, вміти їх інтерпретувати, застосовувати, давати оцінку неправомірної поведінки і передбачати юридичні наслідки.

За результатами навчання проводиться комп’ютерний тестовий контроль. Аналіз результатів комп'ютерного підсумкового тестування, представлений на рисунку 3, свідчить, що рівень отриманих знань слухачів значно перевищує рівень їх базових знань.

Заключний етап циклу - семінар. Для підготовки до нього заздалегідь надаються контрольні запитання. Тобто слухачі готуються протягом всього циклу, опрацьовують нормативно-правові акти, спеціальну та періодичну літературу. В ході семінару вони 
не тільки відповідають на запитання, а й активно обговорюють їх, корегують і доповнюють відпо- віді колег та наводять приклади з особистого професійного досвіду.

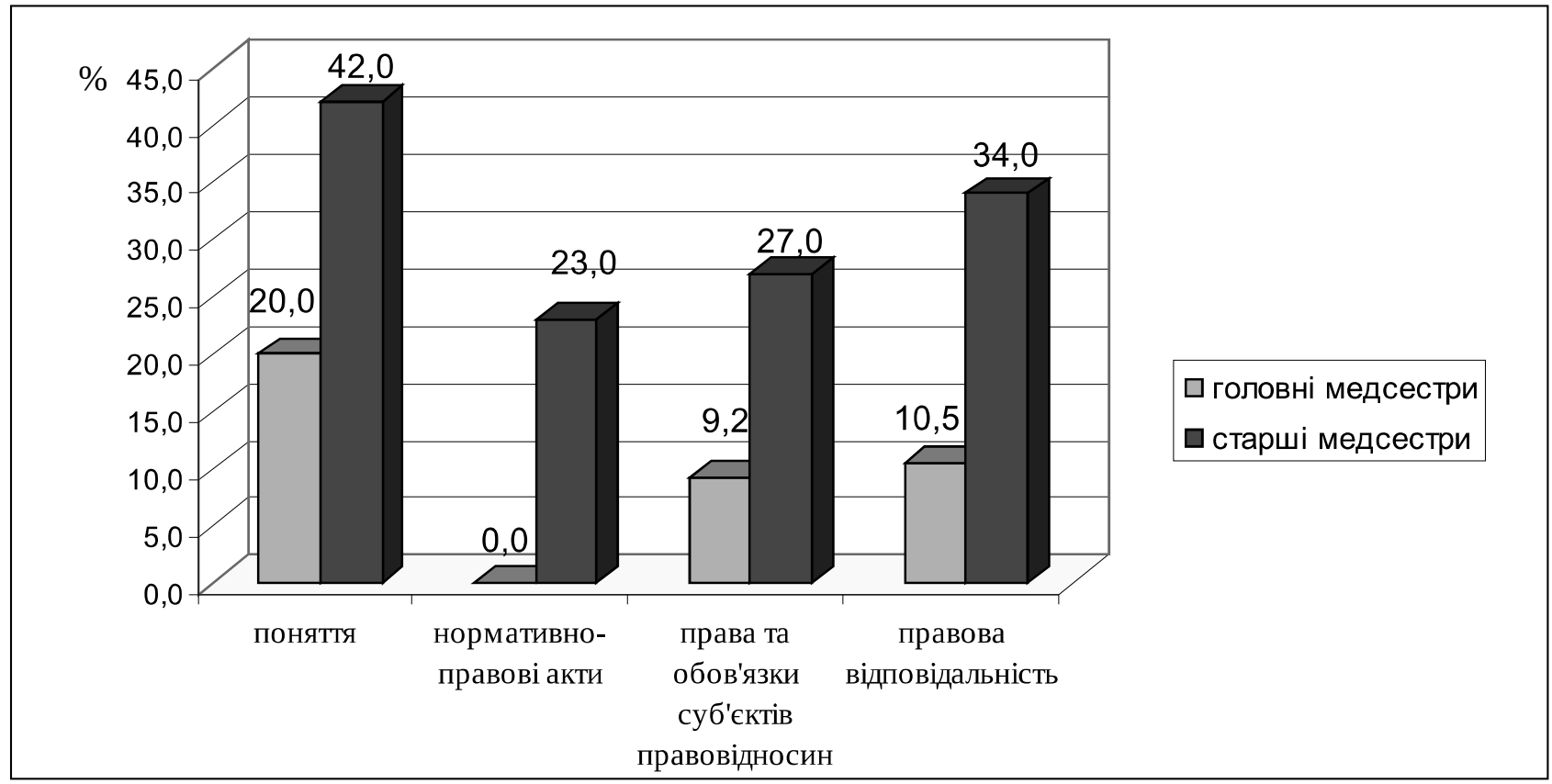

Рис. 2. Результати вхідного контролю знань слухачів (\% неправильних відповідей).

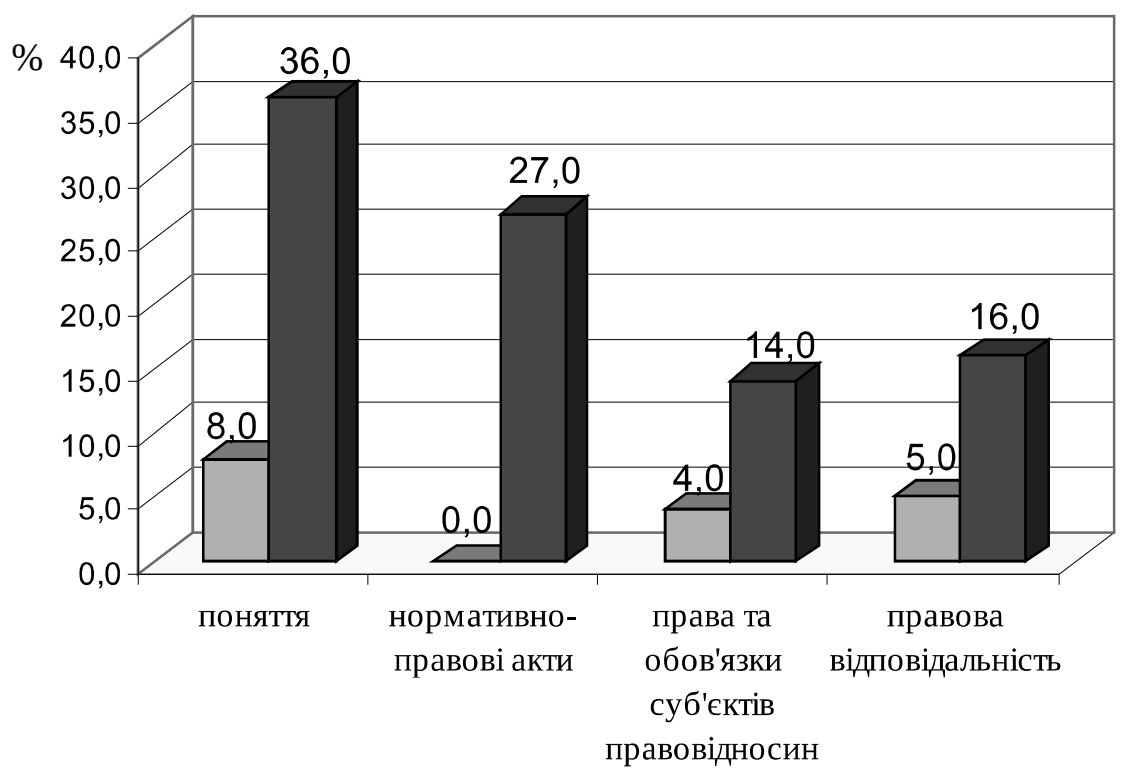

Рис. 3. Результати вихідного (підсумкового) контролю знань слухачів (\% неправильних відповідей).

Висновки та перспективи подальших досліджень. 1. Проведення циклу тематичного удосконалення з медичного права, як сучасної навчальної дисципліни, є особливо актуальним та необхідним, сприяє розвитку професійних компетенцій керівників системи охорони здоров’я України на етапі післядипломної освіти.
2. Вивчення медичного права дозволяє слухачам набути необхідного обсягу правових знань і сформувати навички та вміння вирішення складних управлінських задач щодо правовідносин між медичними працівниками і пацієнтами.

3. Сучасна медична практика вимагає від спеціалістів охорони здоров’я не лише правової поінфор- 
мованості, а й достатнього рівня правових знань, які доводиться застосовувати у щоденній професійній діяльності, тому формування правового мислення не можна відокремлювати від практичної підготовки медичних спеціалістів.

4. Потребує подальшого вдосконалення правова післядипломна підготовка, перепідготовка та підвищення кваліфікації фахівців у галузі охорони здоров'я України.

5. Досвід проведення циклу тематичного удосконалення з медичного права підтверджує актуальність, своєчасність та необхідність впровадження важливої, сучасної навчальної дисципліни у післядипломне навчання керівників медсестринства.

\section{Список літератури}

1. Вороненко Ю. В. Право - важлива складова програми післядипломної підготовки керівників системи охорони здоров’я України / Ю. В. Вороненко, Я. Ф. Радиш // Український медичний часопис. - 2006. № 6 (56). - С. 35-39.

2. Істомін С. В. Медичне право як наука та предмет викладання / С. В. Істомін, Н. П. Кризина // Державне управління: удосконалення та розвиток [Електронне наукове фахове видання]. - 2009. - № 3.

\section{References}

1. Voronenko, Yu.V., \& Radish, Ya.F. (2006). Pravo vazhlyva skladova prohramy pisliadyplomnoi pidhotovky kerivnykiv systemy ohorony zdorovia Ukrainy [Law is an important component of the program of post-graduate training of healthcare system heads in Ukraine]. Ukrainskyi medychnyi chasopys - Ukrainian Medical Journal, 6(56), 35-39 [in Ukrainian].

2. Istomin, S.V., Krysina, N.P. (2016). Medychne pravo yak nauka ta predmet vykladannia [Medical law as a science and subject of teaching]. Derzhavne upravlinnia: udoskonalennia ta rozvytok - Public Administration: Improvement and Development, 3, 2009 [in Ukrainian].
Медичне право стає світоглядною галуззю науки і практичної діяльності. 3 огляду на це, надзвичайно важливим є підвищення уваги до його розвитку та подальша інтеграція зусиль представників медичної і юридичної спільноти, для яких медичне право є об’єднавчим концептом. Проведене дослідження не вичерпує всіх аспектів даної проблематики. Перспективою подальших досліджень буде вивчення важливих аспектів викладання медичного права, пошук шляхів удосконалення правової післядипломної підготовки, перепідготовки та підвищення кваліфікації фахівців галузі охорони здоров’я України.

3. Радиш Я. Ф. Питання медичного права в дисертаційних дослідженнях українських авторів (20042006 років) / Я. Радиш, Н. Кризина // Лікарська справа (Врачебное дело), - 2006. - № 7. - С. 89-94.

4. Стеценко С. Г. Медичне право України : підручник / С. Г. Стеценко, В. Ю. Стеценко, І. Я. Сенюта ; Всеукраїнська асоціація видавців «Правова єдність». - К., 2008. - 507 c.

5. Kennedy Ia. Medical Law / Ian Kennedy, Andrew Grubb. - 3rd ed. - London : Butterworth, 2005. - 2380 p.

3. Radish, Ya.F. (2006). Pytannia medychnoho prava v dysertatsiinykh doslidzhenniakh ukrainskykh avtoriv (20042006 rokiv) [Issues of medical law in dissertation of Ukrainian authors researches (2004-2006.)]. Likarska sprava (Lechebnoe delo) - Medical Practice, 7, 89-94 [in Ukrainian].

4. Stetsenko, S.H., Seniuta, I. Ya. (2008). Medychne pravo Ukrainy: pidruchnyk [Medical Law of Ukraine: Textbook]. Vseukrainska asotsiatsia vydavtsiv "Pravova yednist" Ukrainian Publishers Association "Legal Unity”. Kyiv [in Ukrainian].

5. Kennedy Ian, Grubb Andrew (2005). Medical Law, 3rd ed. London: Butterworth, 2380. 